\title{
Effects of two antihistamine drugs on actual driving performance
}

\author{
TIM BETTS, DIANA MARKMAN, SUSAN DEBENHAM, DEBORAH MORTIBOY, \\ THERESA MCKEVITT
}

\begin{abstract}
A double blind placebo controlled experiment was conducted measuring the effects of the centrally active antihistamine triprolidine and the peripherally acting antihistamine terfenadine on actual driving performance in a group of experienced women drivers.

Triprolidine greatly impaired driving behaviour, whereas terfenadine did not. Triprolidine also impaired subjective and objective measures of mood and arousal, and despite an awareness that their driving was impaired while they were taking this agent subjects could not correct their performance.

This study suggests that drivers who need antihista-
\end{abstract} mine drugs should avoid those that act centrally.

\section{Introduction}

It is often assumed that conventional antihistamine drugsthat is, those which block $\mathrm{H}_{1}$ receptors-impair driving performance. This is because most drugs of this class (used for hay fever and other allergic conditions) are lipid soluble, cross the blood-brain barrier, and affect the central nervous system, causing sedation and impairing laboratory indices of psychomotor function. To our knowledge, however, the assumption that antihistamines impair driving performance has never been formally evaluated with actual car driving tests.

Recently some $\mathrm{H}_{1}$ receptor antagonists have been introduced which do not appear to be centrally active, either because of poor penetrance of the central nervous system or because of selective affinity for peripheral $\mathrm{H}_{1}$ receptor sites. Comparison of two of these drugs (astemizole and terfenadine) with a conventional centrally active antihistamine (triprolidine) ${ }^{1}$ showed that the two non-centrally active drugs did not significantly affect laboratory measures of psychomotor performance, whereas triprolidine did. We therefore decided to compare the effect of a non-centrally acting drug (terfenadine) with that of a centrally active antihistamine (triprolidine) on actual driving performance. To permit comparison with the other study ${ }^{1}$ we recruited women.

\section{Subjects and methods}

We studied 12 experienced women drivers. All drove regularly and

\footnotetext{
University Department of Psychiatry, Clinical Research Block, Queen Elizabeth Hospital, Birmingham B15 2TH

TIM BETTS, MRCPSYCH, senior lecturer

DIANA MARKMAN, DIPCOT, occupational therapist

SUSAN DEBENHAM, MB, senior house officer

DEBORAH MORTIBOY, medical student
}

University Department of Obstetrics and Gynaecology, Birmingham Maternity Hospital, Edgbaston, Birmingham B15 2TH THERESA MCKEVITT, MPHIL, research associate

Correspondence to: Dr Tim Betts. were mostly students or professional members of the University of Birmingham. They were medically and psychologically screened before the study (which was conducted outside the hay fever season) and gave informed consent. The study was approved by the ethical committee of the Queen Elizabeth Hospital, Birmingham. Testing near or during a period was avoided, as was alcohol or other drug use.

Each subject served as her own control and the study was double blind. Subjects were tested on three Sunday mornings at weekly intervals. In a balanced order design subjects took either $60 \mathrm{mg}$ terfenadine on the Friday evening before testing, two $60 \mathrm{mg}$ doses on the Saturday, and a final $60 \mathrm{mg}$ dose on the Sunday morning two hours before testing or $10 \mathrm{mg}$ triprolidine on the Friday, three $10 \mathrm{mg}$ doses on the Saturday and a final $10 \mathrm{mg}$ dose two hours before testing on the Sunday. A matched placebo was taken similarly, a double placebo technique being used to overcome the problem of a different drug regimen on the Saturday (terfenadine has a longer duration of action than triprolidine).

Two hours after taking the Sunday morning dose subjects completed an 18 item visual analogue scale measuring mood, tension, and arousal ${ }^{2}$ and a second visual analogue scale assessing how safe they felt to drive. They then went to a university car park on which two driving tests had been laid out. During the driving tests one of the experimenters (TB) rated the subjects' behaviour on a five item visual analogue scale measuring mood, tension, and arousal.

\section{DRIVING TESTS}

The driving tests were conducted in a standard saloon car, two minutes being allowed for practice beforehand. The two tests were exactly similar to those previously described. ${ }^{3}$ The first is a weaving task. The subject is asked to drive over a course weaving in and out between a line of bollards (the distance between the bollards being one and a half times the length of the car), turn the car, and return through the bollards to the starting point. There are financial penalties for going too slowly or striking bollards. The course is negotiated three times and the mean time to complete the course, the total number of bollards struck, and the number of "mistakes" (stalling, going the wrong way, having to stop or reverse the car to negotiate the course) are recorded.

The second task is a gap acceptance test. This is a circular course over which the subjects drive 10 times without stopping. On each circuit they are presented with a gap formed by two bollards. At a distance of 25 metres they have to decide whether the gap is wide enough for the car, and if they decide that it is then they must accept the gap by driving through it. If they decide that the gap is too narrow then they reject it by driving to the side of it. There are five possible gaps: two are wider than the car by two inches and four inches $(5 \mathrm{~cm}$ and $10 \mathrm{~cm})$, one is the same width as the car but could be negotiated by a careful driver, and two are narrower than the car by two inches and four inches. Each gap is presented twice in random order on each test.

The total time taken, number of correct and incorrect decisions taken, and number of times subjects either strike or successfully pass through gaps which they have accepted to drive through (and which are wide enough) are recorded.

\section{STATISTICS}

Overall differences among scores for the three groups on the visual analogue scale and the driving test scores were tested for significance using Friedman's two way analysis of variance. ${ }^{4}$ If an overall significant difference was found differences between two groups were tested using the Wilcoxon matched pairs signed ranks test. ${ }^{4}$ 


\section{Results}

There were no significant differences between terfenadine and placebo on any of the measures in the driving tests. In the weaving test there was an overall significant difference among the three groups in terms of the time taken, number of bollards struck, and number of mistakes made (table I). Comparison of each group with the others showed that subjects taking triprolidine were significantly slower, struck more bollards, and made significantly more mistakes than when taking either placebo or terfenadine.

In the gap acceptance test subjects in the three groups did not differ significantly in their judgment of a passable gap but there was a significant overall difference in their ability to pass through it without striking it (table II). Subjects taking triprolidine were significantly more likely to strike the gap while negotiating it than when taking either placebo or terfenadine. There was no overall significant difference in the time taken to complete this test.

Scores on the 18 item subjective visual analogue scale showed overall significant differences in arousal (alert-drowsy and well coordinated-clumsy) and a significant difference in mood (outward going-self centred) (table III). On the measures of arousal there were no significant differences between terfenadine and placebo: triprolidine significantly impaired the subjective feeling of arousal and also impaired subjective appreciation of mood as compared with terfenadine and placebo.

TABLE I-Weaving test results

\begin{tabular}{lllll}
\hline & Triprolidine & Terfenadine & Placebo & $\begin{array}{c}\text { Overall } \\
\text { difference } \\
\text { (p value) }\end{array}$ \\
\hline Mean time in seconds(SD) & $66 \cdot 0(16 \cdot 8)^{*}$ & $56 \cdot 9(13 \cdot 5)$ & $60 \cdot 6(13 \cdot 6)$ & $<0.05$ \\
Total No bollards struck & $42^{* *}$ & 22 & 14 & 0.02 \\
Total No of "mistakes" & $22^{* *}$ & 7 & 7 & 0.01 \\
\hline
\end{tabular}

Triprolidine compared with terfenadine and placebo: ${ }^{*} \mathrm{p}<0.05 ;{ }^{* *} \mathrm{p}<0.025$

TABLE II-Gap acceptance test (passable gap defined as gap wide enough to drive car through)

\begin{tabular}{lcccc}
\hline & Triprolidine & Terfenadine & Placebo & $\begin{array}{c}\text { Overall } \\
\text { difference } \\
\text { (p value) }\end{array}$ \\
\hline $\begin{array}{c}\text { Total No of passable gaps } \\
\text { attempted (impassable } \\
\text { gaps attempted) }\end{array}$ & $60(19)$ & $57(20)$ & $57(23)$ & NS \\
$\begin{array}{c}\text { Total No of passable gaps } \\
\text { successfully negotiated } \\
\text { (number struck) }\end{array}$ & $17^{* * *}(43)$ & $29(28)$ & $32(25)$ & $<0.02$ \\
\hline
\end{tabular}

Triprolidine compared with terfenadine and placebo: ${ }^{* * *} \mathrm{p}<0.01$.

TABLE III-Mean scores from subjective visual analogue scale. High scores represent impairment. ( $S D$ in parentheses)

\begin{tabular}{|c|c|c|c|c|}
\hline & Triprolidine & Terfenadine & Placebo & $\begin{array}{c}\text { Overall } \\
\text { difference } \\
\text { ( } \mathrm{p} \text { value) }\end{array}$ \\
\hline \multirow{2}{*}{$\begin{array}{l}\text { Alert-drowsy } \\
\text { Well coordinated } \\
\text { Outward going-self } \\
\text { centred }\end{array}$} & $\begin{array}{l}62 \cdot 2(15 \cdot 7)^{* *} \\
61 \cdot 9(15 \cdot 6)^{* *}\end{array}$ & $\begin{array}{l}34 \cdot 4(20 \cdot 8) \\
32 \cdot 7(20 \cdot 7)\end{array}$ & $\begin{array}{l}41 \cdot 2(21 \cdot 9) \\
39 \cdot 7(22 \cdot 8)\end{array}$ & $\begin{array}{l}<0.05 \\
<0.02\end{array}$ \\
\hline & $40.7(20.9)^{*}$ & $27 \cdot 9(22 \cdot 7)$ & $30 \cdot 8(12 \cdot 7)$ & $<0.01$ \\
\hline
\end{tabular}

Triprolidine compared with terfenadine and placebo: ${ }^{*} \mathrm{p}<0.05 ;{ }^{* *} \mathrm{p}<0.025$.

TABLE IV-Mean score on visual analogue scale for subjective assessment of driving. High score represents unfit. (SD in parentheses)

\begin{tabular}{lllll}
\hline & Triprolidine & Terfenadine & Placebo & $\begin{array}{c}\text { Overall } \\
\text { significance } \\
\text { (p value) }\end{array}$ \\
\hline $\begin{array}{l}\text { Fit to drive-unfit to } \\
\text { drive }\end{array}$ & $45.6(24.6)^{* *}$ & $22.7(28.5)$ & $28.4(25.0)$ & $<0.05$ \\
\hline
\end{tabular}

Triprolidine compared with terfenadine: **p $<0.025$
TABLE V-Mean scores on visual analogue scale for objective categories. High scores represent impairment. ( $S D$ in parentheses)

\begin{tabular}{lcccc}
\hline & Triprolidine & Terfenadine & Placebo & $\begin{array}{c}\text { Overall } \\
\text { difference } \\
\text { (p value) }\end{array}$ \\
\hline Mood & $65.9(22 \cdot 5)^{* *}$ & $42 \cdot 5(18 \cdot 2)$ & $48 \cdot 7(15 \cdot 9)$ & 0.02 \\
Irritability & $67.9(22 \cdot 7)^{*}$ & $56 \cdot 2(12 \cdot 5)$ & $63.4(13 \cdot 5)$ & 0.05 \\
Sleepiness & $43.5(32 \cdot 6)^{* *}$ & $10 \cdot 8(22 \cdot 3)$ & $9 \cdot 4(9 \cdot 5)$ & 0.01 \\
\hline
\end{tabular}

Triprolidine compared with terfenadine: *p< 0.05 .

Triprolidine compared with terfenadine and placebo: ${ }^{* *} \mathrm{p}<0.025$.

The subjective visual analogue scale assessing fitness to drive ("completely fit-totally unfit") showed an overall significant difference. Between group comparison showed that subjects taking terfenadine felt significantly more fit to drive than subjects taking triprolidine (there was no significant difference between triprolidine and placebo) (table IV).

Objective assessment of the subjects (table V) confirmed their subjective appreciation of themselves: subjects taking triprolidine compared with when they were taking terfenadine or placebo were rated as being significantly more depressed and sleepy: no significant differences were observed between terfenadine and placebo. Subjects taking triprolidine were rated as significantly more irritable than when taking terfenadine.

\section{Comment}

In this study the centrally active antihistamine triprolidine impaired performance in two actual driving tests, whereas the non-centrally acting agent terfenadine did not. The tests were designed to reflect factors known to be important in road accidents. ${ }^{5}$ Our drivers were aware of increased feelings of drowsiness and a change in driving fitness while taking triprolidine (and their increased drowsiness was detectable by an observer) but were unable to correct their driving to compensate. Further studies will be needed to assess whether the same effect occurs in men and whether the effect persists or disappears with continual use of triprolidine.

Our study does, however, suggest that centrally active antihistamine drugs do impair driving performance for at least the first few doses in women and increase the risk of a road accident while being taken. The study also suggests that being aware of impairment does not prevent a deterioration in driving skills, so that advice to the effect of "take more care if you feel drowsy" is not appropriate. Doctors who prescribe centrally active antihistamines to people who drive should advise them to stop driving or should consider using a non-centrally acting antihistamine or some other treatment for the allergic condition.

We thank the subjects for their cooperation; Professor J R Newton, of Birmingham Maternity Hospital, for departmental facilities for some of the tests; Dr H Masheter, of Merrell Pharmaceuticals, for the drugs and placebos; Victoria Betts for help with marshalling and data transcription; Peter Harvey for statistical advice; and the security and traffic control staff of the Queen Elizabeth Hospital, Birmingham, for their cheerful cooperation.

\section{References}

${ }^{1}$ Nicholson AW, Stone BM. Performance studies with the $\mathrm{H}_{1}$-histamine receptor antagonists, astemizole and terfenadine. $\mathrm{Br} \mathcal{F}$ Clin Pharmacol 1982;12:199-202.

${ }^{2}$ Betts TA, Blake AE. The psychotropic effects of atenolol in normal subjects. Postgrad Med F 1977;53:151-6.

${ }^{3}$ Betts TA, Birtle J. Effect of two hypnotic drugs on actual driving performance next morning. Br Med $\mathcal{f} 1982 ; 285: 852$.

4 Siegel S. Non parametric statistics for the behavioral sciences. New York: McGraw-Hill, 1956.

${ }^{5}$ Clayton AB. The effect of psychotropic drugs on driving related skills. Hum Factors 1976;18:241-52.

(Accepted 24 October 1983) 